\title{
Kolesteatom Kongenital dengan Komplikasi Abses Retroaurikula
}

\author{
Indriani, Yan Edward, Rossy Rosalinda
}

\begin{abstract}
Abstrak
Kolesteatom kongenital dapat tumbuh di telinga tengah, apeks petrosus dari tulang temporal dan mastoid. Penyakit in biasanya ditemukan secara tidak sengaja saat melakukan tomografi komputer atau setelah ada komplikasi. Salah satu komplikasi yang sering terjadi adalah mastoiditis yang menyebabkan abses retroaurikula. Diagnosis kolesteatom kongenital ditegakkan apabila ditemukan kolesteatom tanpa perforasi membran timpani, riwayat otore maupun riwayat operasi telinga sebelumnya. Operasi adalah terapi mutlak pada kasus ini. Dilaporkan satu kasus kolesteatom kongenital dengan komplikasi abses retroaurikula pada seorang anak perempuan berusia 12 tahun. Pada pasien ini dilakukan tindakan timpanomastoidektomi dinding utuh, yang di follow up selama 3 bulan dengan hasil yang memuaskan. Abses retroaurikula merupakan salah satu komplikasi kolesteatom kongenital yang sering menjadi awal gejala adanya kolesteatom kongenital. Deteksi dini dan tatalaksana yang tepat akan memberikan hasil yang maksimal.
\end{abstract}

Kata kunci: abses retroaurikula, kolesteatom kongenital, membran timpani utuh

\begin{abstract}
Congenital cholesteatoma may originate in the middle ear, in the petrous apex of the temporal bone, and in the mastoid compartment. This disease coincidently found when performing CT scan or there was a complication. One of the complications is mastoiditis with retroarticular abscess. The diagnose of congenital cholesteatoma was established by found cholesteatoma with intact tympanic membrane, no history of ear discharge, and no history of ear operated before. It has been reported a case of congenital cholesteatoma with retroarticular abscess complication in a 12-yearold girl. In this patient performed canal wall up tympanomastoidectomy, that follow up for three months and the postoperative result is satisfied. Retroauricula abscess is one of the congenital cholesteatoma complications that usually become the first sign of congenital cholesteatoma. Early detection and correct management will give a satisfied result.
\end{abstract} Keywords: congenital cholesteatoma, intact tympanicmembran, retroarticular abscess

Affiliasi penulis: Bagian THT-KL, Fakultas Kedokteran, Universitas Andalas, Padang, Indoensia.

Korespondensi: Indriani, Email: fakhrind@gmail.com

Telp:+62 85274779954

\section{PENDAHULUAN}

Kolesteatom kongenital merupakan suatu massa yang terlihat seperti mutiara putih di balik membran timpani yang utuh. Penyakit ini merupakan sisa jaringan epitel embrio yang tertinggal pada telinga tanpa adanya perforasi membran timpani dan riwayat infeksi telinga. ${ }^{1,2}$

Kolesteatom kongenital dapat berasal dari lima tempat pada tulang temporal: mastoid petrosa, cerebellopontin angle, kavum timpani, meatus akustikus eksterna, dan prosesus mastoid. Gejala dari kolesteatom kongenital bervariasi dari yang tidak bergejala sampai terjadinya peningkatan tekanan intrakranial. Salah satu gejala yang pertama kali muncul pada pasien dengan kolesteatom kongenital adalah abses subperiosteal. ${ }^{3,4}$

\section{Etiologi dan Patogenesis}

Etiologi dan patogenesis kolesteatoma kongenital ini masih kontroversial. Ada beberapa teori tentang etiologi dari kolesteatom kongenital ini. ${ }^{2,5}$ 
a) Adanya sisa jaringan epidermis ektopik.

b) Pertumbuhan abnormal dari meatal epidermis. Mesenkim disekitar meatal plate membentuk lamina propria (lapisan fibrosa) dari membrane timpani dan pada usia gestasi minggu ke- 9 dikeliling oleh 4 lapisan membran ossea yang akan membentuk tympanic ring, tympanic ring ini nantinya yang akan menyokong membrane timpani. Berdasarkan teorinya, tympanic ring berfungsi untuk menghambat migrasi epitel, kegagalan fungsi ini akan menyebabkan terjadinya kolesteatom kongenital pada first junction dan arkus brankial kedua. ${ }^{6.7}$,

c) Adanya metaplasia yang diikuti oleh infeksi/ inflamasi.

d) Refluk dari cairan amnion yang berisikan epitel skuamosa in utero ke telinga tengah

\section{Klasifikasi}

Derlacki dan Clemis $^{9}$ membagi kolesteatom kongenital menjadi 3 tipe :

1. Tipe piramid petrosa

2. Tipe mastoid

3. Tipe timpani

Berdasarkan morfologinya, kolesteatom kongenital ini diklasifikasikan menjadi beberapa tipe, yaitu: tipe tertutup (tipe kista) dan tipe terbuka (tanpa adanya pembentukan epitel kista), dan tipe campuran. Berdasarkan bentuknya kolesteatom kongenital terbagi menjadi: bundar, constricted, irregular (multilobular) dan bentuk lain yang tidak diklasifikasikan. ${ }^{10,11}$

\section{Abses Retroaurikula}

Mastoiditis atau abses mastoid subperiosteal merupakan komplikasi terbanyak dari otitis media dengan kolesteatoma. Ada 3 tipe dari abses subperiosteal mastoid ini : posterior subperiosteal disebut juga post aurikula, inferior subperiosteal disebut juga sternocleidomastoideus atau abses bezold, dan anterior subperiosteal yang biasa disebut abses zigoma. ${ }^{4,12}$

Abses retroaurikula adalah abses yang paling sering terjadi pada kasus mastoiditis. Abses ini terbentuk tepat diatas segitiga Mc Ewan, pus berjalan sepanjang jalur vaskuler dari lamina kribosa. ${ }^{13}$

Terdapat dua mekanisme yang menjadi penyebab osteolisis pada proses destruksi tulang akibat kolesteatom yaitu penekanan yang menyebabkan reabsorpsi tulang dan hancurnya tulang secara enzimatik melalui proses inflamasi mediasi sitokin. Terbentuknya abses subperiosteal biasanya berhubungan dengan terhambatnya resesus epitympanum pada telinga tengah, additus ad antrum dan kavum mastoid. ${ }^{4,13}$

\section{Diagnosis}

Menurut Derlacki-Clemis seperti yang dikutip Eric dan Smouha, diagnosis kolesteatom kongenital harus pada telinga normal, tanpa ada riwayat infeksi telinga tengah sebelumnya. Biasanya sering ditemukan pada anak-anak yang rutin melakukan pemeriksaan fisik. ${ }^{14}$ Gejala klinis kolesteatom kongenital tergantung dari ukuran massa, lokasi dan histologinya. Gambaran yang paling sering adalah massa berwarna putih di daerah retrotimpani. Lokasi paling sering dari kolesteatom kongenital adalah pada kuadran anterosuperior membran timpani. ${ }^{5}$

Lesi yang terdapat di anterior dan posterior dapat menyebabkan tuli konduksi. Lesi pada bagian posterior dapat merusak osikel sehingga tuli konduksi yang terjadi adalah akibat terganggunya pergerakan osikuler atau adanya diskontinuitas. Sedangkan lesi di anterior, tuli konduksi terjadi akibat gangguan fungsi tuba eustachius dan efusi pada telinga tengah. ${ }^{5}$ Otalgia dan otorea jarang terjadi. Jika kolesteatom mengenai labirin, pasien dapat menderita vertigo dan tuli sensorineural. $^{5}$

\section{Penatalaksanaan}

Peningkatan kewaspadaan terhadap kolesteatom kongenital baik dari fasilitas kesehatan primer (dokter umum), dokter anak, dokter THT-KL dan penggunaan otoendoskopi yang yang semakin berkembang menyebabkan angka kejadian kolesteatom kongenital semakin banyak ditemukan. Penatalaksanan yang segera pada kasus ini sangatlah penting. ${ }^{6}$

Tujuan dari pembedahan pada kolesteatom kongenital adalah mengangkat kolesteatom secara keseluruhan, melindungi dan meningkatkan pendengaran serta mencegah terjadinya angka kekambuhan. Beberapa teknik pembedahan telah dilakukan pada penyakit ini seperti timpanoplasti, timpanomastoidektomi dinding utuh dan 
timpanomastoidektomi dinding runtuh. Pada stadium awal kolesteatom kongenital dapat dilakukan teknik MITM (Minimally Invasive Transcanal Myringotomy). ${ }^{6}$ Pendekatan pembedahan dilakukan berdasarkan lokasi, tipe kolesteatoma dan pengalaman operator. ${ }^{6}$

\section{KASUS}

Seorang anak perempuan berusia 11 tahun datang ke Poliklinik THT-KL RSUP Dr. M. Djamil Padang pada tanggal 6 September 2017 dengan keluhan utama telinga kanan berdarah sedikit-sedikit sejak 1 bulan yang lalu. Keluhan ini pernah dirasakan 1 tahun yang lalu dan pasien berobat ke RS swasta dan ditemukan ada jaringan di dalam liang telinga, jaringan tersebut kemudian diekstraksi dan dilakukan pemeriksaan histopatologi dengan hasil jaringan granulasi. Riwayat bengkak dibelakang telinga kanan 8 bulan yang lalu, bengkak dan merah disertai keluar nanah, pasien berobat ke RS swasta dan mendapat obat. Tiga bulan kemudian muncul bengkak lagi dan keluar nanah sampai pasien berobat ke poli THT-KL RSUP DR. M. Djamil. Penurunan pendengaran ada sejak 8 bulan yang lalu, terutama pada telinga sebelah kanan.

Tidak terdapat demam, wajah mencong, pusing berputar, nyeri kepala hebat yang disertai mual dan muntah, penurunan kesadaran. Tidak terdapat riwayat trauma pada telinga kanan dan riwayat operasi telinga sebelumnya. Pada pemeriksaan fisik didapatkan status umum keadaan umum baik, kesadaran komposmentis dan tidak demam.

Pada status lokalis THT didapatkan telinga kanan: daun telinga tidak ada kelainan, tidak terdapat nyeri tekan tragus dan nyeri tarik daun telinga, terdapat bengkak di retroaurikula dan hiperemis, perdarahan aktif ada, pustul ada, liang telinga lapang sekret campur darah dan berbau, terdapat jaringan granulasi menutupi sebagian membran timpani. Membran timpani tidak bisa dinilai secara keseluruhan. Pada telinga kiri; daun telinga tidak ada kelainan, retroaurikuler tidak ada kelainan, liang telinga lapang. Membran timpani utuh refleks cahaya ada. Pada pemeriksaan hidung dan tenggorok dalam batas normal. Pada leher tidak ditemukan adanya pembesaran kelenjar getah bening.

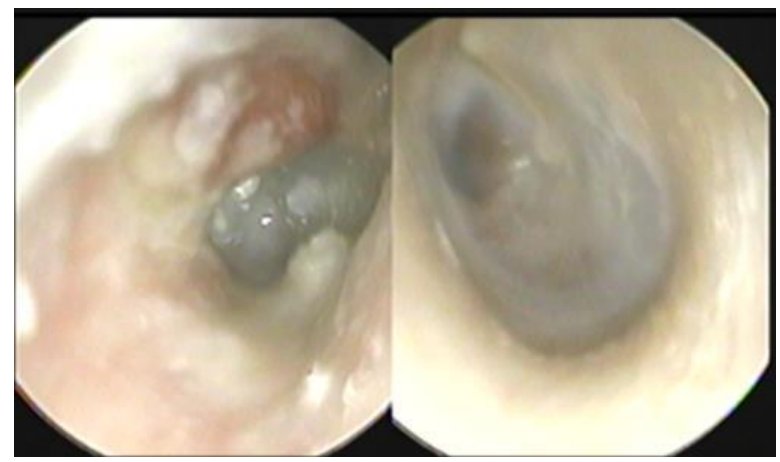

Gambar 1. Otoskopi telinga kiri sebelum operasi

Pada pemeriksaan fungsi keseimbangan dan saraf fasialis tidak ditemukan kelainan. Pemeriksaan audiometri didapatkan telinga kanan tuli konduksi derajat ringan dengan ambang dengar 33,75 dB, telinga kiri normal dengan ambang dengar $12,5 \mathrm{~dB}$

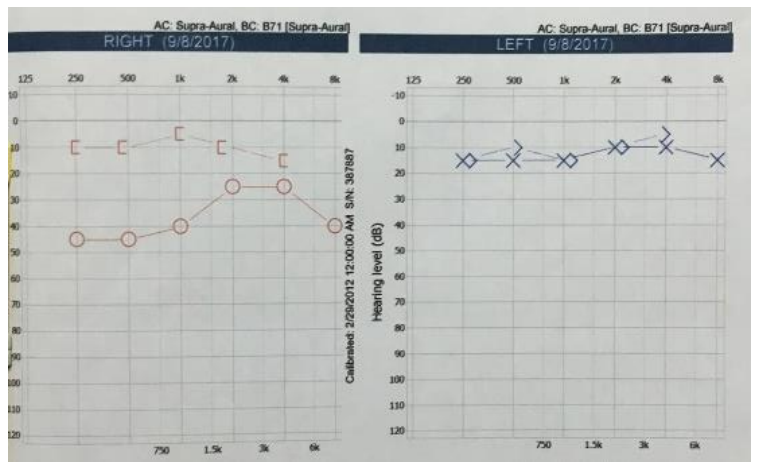

Gambar 2. Audiometri telinga sebelum operasi

Pasien sudah dilakukan pemeriksaan CT scan pada rumah sakit swasta dan didapatkan kesan: mastoiditis kanan

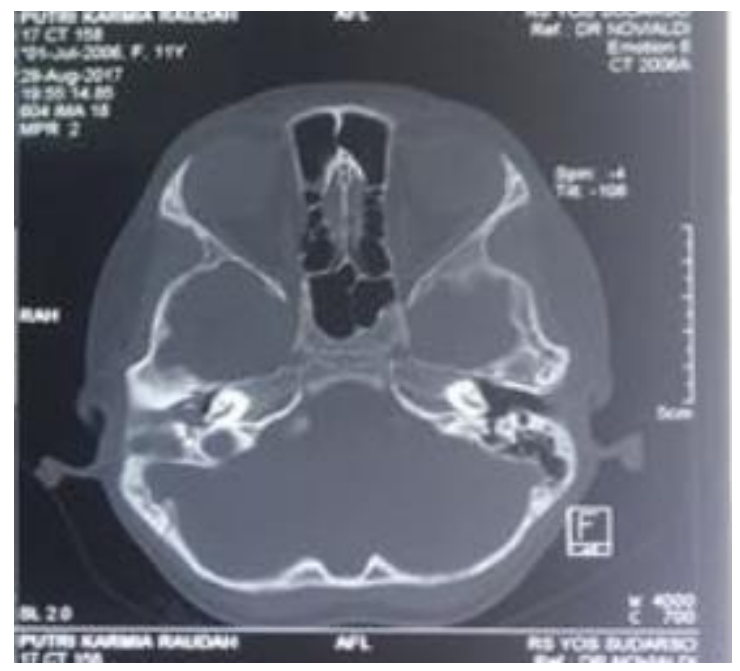

Gambar 3. CT scan mastoid 
Pada CT scan mastoid sebelah kanan terlihat ada perselubungan menutupi seluruh epitympanum dan sebagian dari mesotimpanum, perselubungan berbatas tegas. Tulang-tulang pendengaran tidak terlihat. Dinding posterior liang telinga kanan terlihat destruksi. Sedangkan mastoid terlihat sklerotik dan terlihat perselubungan di daerah antrum, additus ad antrum terpapar. Kanalis semisirkularis dan koklea tidak terpapar. Tegmen timpani, tegmen mastoid, dan sinus signus sigmoid tidak terpapar.

Pada telinga sebelah kiri pneumatisasi air cell mastoid baik, kavum timpani dan kavum mastoid baik, tulang-tulang pendengaran tervisualisasi dengan baik. Kanalis semisrkularis dan koklea baik. Tegmen timpani, tegmen mastoid, sinus sigmoid baik.

Diagnosis pada saat itu ditegakkan suspek otitis media supuratif kronis (OMSK) tipe bahaya auris dekstra (AD). Diagnosis banding kolesteatom kongenital dan tumor telinga AD. Dilakukan kultur dan uji kepekaan dari sekret liang telinga kanan. Kemudian dilakukan ekstraksi jaringan granulasi dan dipasang tampon albothyl pada telinga kanan. Cefadroksil sirup $2 \times 500 \mathrm{mg}$, paracetamol $3 \times 500 \mathrm{mg}$, dan tarivid otic 2 $x 5$ tetes telinga kanan.

Pasien kontrol kembali pada tanggal 11 September 2017 dengan kondisi yang sama, dimana jaringan granulasi sudah menutupi liang telinga kanan kembali. Hasil kultur didapatkan kuman Pseudomonas aeruginosa dan peka terhadap gentamisin, seftazidim, cefepim, amikasin, dan meropenem. Ditegakkan diagnosis suspek OMSK AD tipe kolesteatom diagnosis banding kolesteatom kongenital $A D$ dan tumor telinga $A D$. Dilakukan pengangkatan jaringan granulasi dan pemasangan tampon pada telinga kanan, obat sebelumnya diteruskan. Diagnosis ditegakkan suspek OMSK AD tipe kolesteatom dengan diagnosis banding kolesteatom kongenital dan tumor telinga. Direncanakan dilakukan operasi timpanomastoidektomi dinding runtuh $A D$ dalam narkose umum.

Pada tanggal 8 September 2017 didapatkan hasil pemeriksaan darah; haemoglobin: 14,1 gr/dl, leukosit: 6.620/mm3, hematokrit: 42\%, trombosit: 310.000/mm3, PT: 10,6", APTT: 39,8".

Tanggal 17 September 2017 pasien dirawat dengan diagnosis suspek OMSK AD tipe bahaya, dengan diagnosis banding kolesteatom kongenital dan tumor telinga $A D$, untuk dilakukan timpanomastoidektomi dinding runtuh $A D$ dalam narkose umum. Terapi diberikan injeksi gentamisin $2 \times 20 \mathrm{mg}$ iv.

Pada tanggal 19 September 2017 pasien dilakukan Tindakan operasi. Operasi dimulai dengan pasien tidur terlentang di meja operasi dalam narkose umum dan teknik hipotensi. Dilakukan tindakan aseptik dan antiseptik pada lapangan operasi dan dipasang duk steril. Dilakukan evaluasi telinga kanan dengan menggunakan mikroskop, terlihat liang telinga sempit terdapat jaringan granulasi, membran timpani tidak dapat dinilai. Dibuat penandaan pada lokasi 3 $\mathrm{mm}$ dari sulkus retroaurikular dekstra dan dilakukan infiltrasi pada empat regio retroauricula dan empat regio di liang telinga dekstra dengan epinefrin 1:100.000. Insisi pada daerah penandaan tegak lurus terhadap kulit dan tangensial terhadap liang telinga. Dipasang retraktor dan korteks mastoid dipaparkan. Dibuat garis imajiner membentuk segitiga Mc Ewan sebagai penanda dalam melakukan pengeboran pada korteks mastoid. Tampak kolesteatom memenuhi kavum mastoid, kavum mastoid dibersihkan Pengeboran dilanjutkan dengan tetap mempertahankan dinding posterior liang telinga.

Tampak bagian bawah dinding posterior liang telinga destruksi dan terdapat kolesteatom dan jaringan granulasi. Kolesteatom dan jaringan granulasi dibersihkan. Tampak kolesteatom di kavum timpani terutama daerah epitimpanum. Tulang-tulang pendengaran sudah tidak ada. Kolesteatom dibersihkan dan terlihat membran timpani utuh. Jaringan sekitar membran timpani dibersihkan. Dilakukan pemasangan graft (kartilago septum) pada daerah bawah dinding posterior liang telinga. Dilakukan timpanomeatal flap, kemudian dilakukan pemasangan graft dari fasia profunda secara underlay. Kemudian dipasang spongostan untuk menopang MT, kemudian dipasang tampon dalam dan dilakukan penjahitan luka operasi lapis demi lapis. Dipasang verban dan balut tekan. Operasi selesai. Lama operasi berkisar 3 jam. Diagnosis pasca operasi post timpanomastoidektomi dinding utuh atas indikasi kolesteatom kongenital telinga kanan. Terapi diberikan injeksi gentamisin 2x20 miligram iv selama 3 hari, 
tramadol drip $100 \mathrm{mg}$ dalam 500cc RL per 8 jam (selama 1 hari). Pada folow up segera setelah operasi tidak ditemukan wajah mencong dan pusing berputar. Pada tanggal 20 september 2017, keadaan umum sedang, sadar, keluhan pusing berputar tidak ada, wajah mencong tidak ada, demam tidak ada. Terapi dilanjutkan dengan injeksi gentamisin 2 × $40 \mathrm{mg}$ iv, Parasetamol 3x500 mg per oral.

Tanggal 18 oktober 2017 pasien kontrol kembali. Luka post operasi baik, liang telinga lapang sekret tidak ada, membran timpani utuh.

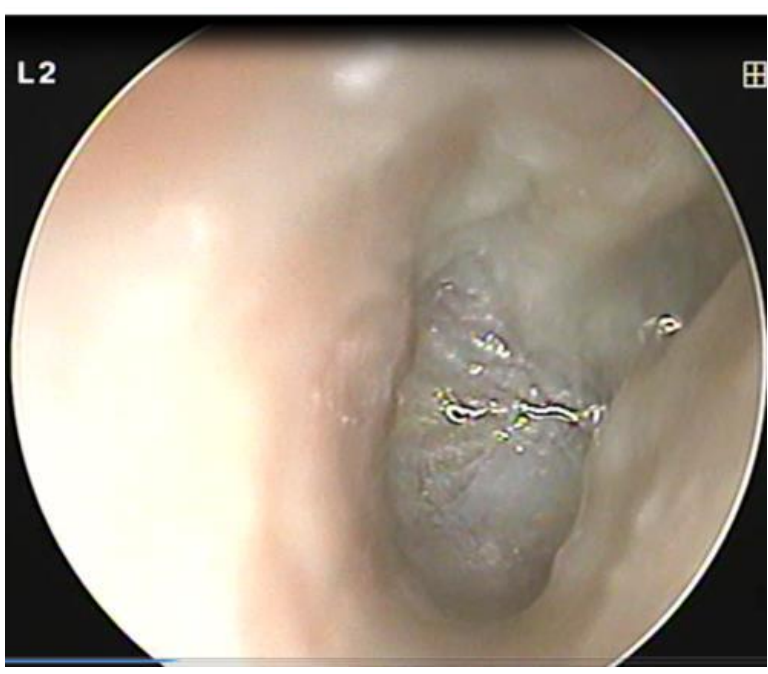

Gambar 4. Otoskopi 1 bulan post-operasi

Tanggal 9 Desember 2017 pasien kontrol kembali, keadaan umum pasien baik keluhan tidak ada. Membran timpani utuh, luka post operasi tenang. Pada pasien dilakukan audiometri ulang dengan hasil ambang dengar pada telinga kanan $36,25 \mathrm{db}$ dan 7,5 $\mathrm{db}$ pada telinga kanan.

\section{PEMBAHASAN}

Dilaporkan satu kasus seorang anak perempuan 12 tahun dengan diagnosis kolesteatom kongenital dengan komplikasi abses retroaurikula. Kolesteatom kongenital merupakan kasus yang jarang ditemukan. Berkisar 2\% - 5\% dari seluruh kasus kolesteatom, $10 \%-28 \%$ dari kasus kolesteatoma pada anak. ${ }^{1,5}$

Migirov et al menemukan 7 kasus abses subperiosteal yang menjadi salah satu gejala awal adanya kolesteatom kongenital pada anak. ${ }^{4}$

Diagnosis sebelum operasi diduga OMSK maligna $A D$ karena dalam perjalanan penyakit terdapat jaringan granulasi di liang telinga kanan yang mengakibatkan keluar darah yang bercampur sekret sejak 8 bulan sebelum operasi dan adanya abses subperiosteal, pada tomografi komputer terlihat adanya gambaran hipodens dengan destruksi tulang. Penurunan pendengaran, membran timpani sukar dinilai sampai saat operasi. Berdasarkan temuan operasi dimana membran timpani utuh ditegakkan diagnosis kolesteatom kongenital telinga kanan. Ini sesuai dengan kriteria Derlacki dan Clemis yang kemudian dimodifikasi oleh Levenson menyatakan bahwa diagnosis kolesteatom kongenital ditegakkan jika ditemukan kolesteatom dengan membran timpani yang utuh, tidak ada riwayat otore maupun operasi telinga sebelumnya. ${ }^{16}$

Kolesteatom kongenital sering terlambat didiagnosis karena pada awalnya tidak memberikan gejala. Biasanya pasien datang setelah ada komplikasi yang sulit dibedakan dengan OMSK maligna. Park Ho et al mendiagnosis pasien kolesteatom kongenital setelah lesi meluas mengenai mastoid sebanyak 17 (63\%) dari 27 kasus. $^{17}$

Gejala klinis pada pasien ini berupa abses retroaurikula, penurunan pendengaran, keluar secret yang bercampur darah dari liang telinga. Steward et al mendapatkan bahwa penurunan pendengaran dan otore merupakan keluhan terbanyak dilaporkan pasien masing-masing $73 \%$ dan 55\%. Otore terjadi akibat adanya kolesteatom yang mendestruksi dinding posterior liang telinga sehingga terbentuk jaringan granulasi. Kolesteatom dapat mengalami infeksi sehingga menimbulkan gejala seperti OMSK. ${ }^{18}$

Pada temuan operasi didapatkan kolesteatom di mastoid dan di kavum timpani. Kolesteatom kongenital di mastoid dapat terjadi akibat sisa epitel yang terperangkap pada saat penutupan celah neural yang terjadi antara minggu ke-3 dan ke-6 usia janin. ${ }^{1,15}$

Pemeriksaan kultur dan uji kepekaan dari sekret perlu dilakukan untuk mengetahui kuman penyebab infeksi serta untuk dapat mengetahui obat yang sesuai terhadap kuman penyebab. Pada pasien ini ditemukan kuman penyebab Pseudomonas aureginosa yang merupakan kuman patogen oportunistik di dalam tubuh. Kuman ini dapat menginfeksi pada saat tubuh dalam kondisi yang lemah. Antibiotik yang peka gentamisin sedangkan seftazidime dan moksifloksasin 
intermediet. Pada kultur dan uji kepekaan dari secret telinga saat operasi didapatkan kuman penyebab yang sama Pseudomonas sp. Kuman terbanyak yang ditemukan dalam infeksi telinga dengan kolesteatom adalah Pseudomonas sp, Streptococcus, dan Staphylococcus. ${ }^{19}$

Pemeriksaan penunjang tomografi komputer potongan aksial dan koronal diperlukan untuk menentukan lokasi kolesteatom serta perluasannya. ${ }^{2,4}$ Pada pasien ini terlihat adanya gambaran hipodens didaerah mastoid kanan, destruksi mastoid, dinding posterior liang telinga destruksi, kanalis semisirkularis utuh.

Pada pasien ini dilakukan operasi pengangkatan kolesteatom kongenital dengan timpanomastoidektomi dinding utuh. Pemilihan jenis operasi ini dilakukan karena pada pasien ini lesi mengenai dan mendestruksi mastoid dan sebagian dinding posterior liang telinga, membran timpani utuh. Tindakan operasi pada kasus kolesteatom kongenital sangat variatif sesuai dengan tempat dan luas kolesteatom itu sendiri. Para penulis telah membagi tipe atau stadium dari kolesteatom kongenital yang menggambarkan luas dari kolesteatom tersebut, namun belum ada satu kesepakatan tentang tipe stadium dimaksud. Potsic et al ${ }^{10}$ membagi kolesteatom menjadi 4 stadium yaitu;

1. Mengenai satu kuadran tidak mengenai tulang pendengaran dan mastoid.

2. Mengenai tulang pendengaran

3. Tidak mengenai mastoid

4. Telah mengenai mastoid

Tindakan operasi sesuai dengan stadium atau tipe kolesteatom dimaksud, pada stadium 1 dan 2 atau tipe 1 dapat dilakukan timpanotomi. Stadium 3 atau tipe 2 dilakukan timpanotomi yang diperluas tapi kadang juga memerlukan atikotomi atau timpanomastoidektomi dengan dinding utuh. Pada stadium 4 atau tipe 3 dilakukan timpanomastoidektomi dengan dinding runtuh. Park et al melakukan operasi pada 17 kasus kolesteatom kongenital stadium 4 dengan; timpanomastoidektomi dinding utuh sebanyak $10(59 \%)$ kasus, timpanomastoidektomi dinding runtuh 7 (41\%) kasus dan ossikuloplasti 4 (23,5\%) kasus. ${ }^{17}$

Pemeriksaan audiometri sebelum operasi didapatkan tuli konduksi telinga kanan dengan gap antara hantaran tulang dan hantaran udara sebesar
33,25 dB. Ini melebihi kemampuan amplifikasi membran timpani dan tulang-tulang pendengaran yang berkisar antara 25- 30 dB.20 Tuli konduktif sebesar 30-50 dB kemungkinan telah terdapat diskontinuitas rangkaian tulang pendengaran atau mungkin akibat adanya jaringan granulasi di liang telinga luar yang berfungsi seperti sumbatan telinga.

Empat bulan post operatif didapatkan ambang dengar pasien ini naik 1,25 dB. Sesuai yang dikemukakan oleh Benett et al bahwa peningkatan ambang dengar pada stadium lanjut tidak terlalu signifikan. $^{5}$

Kolesteatom yang terbatas di daerah kuadran anterosuperior telinga tengah jarang mengalami kekambuhan, ini dapat dideteksi dengan pemeriksaan otoskop. Kekambuhan akan meningkat kolesteatom telah meluas. Ekplorasi ulang merupakan tindakan yang harus dilakukan jika terjadi kekambuhan. ${ }^{2,4,5}$ Park et al mendapatkan kekambuhan sebanyak 2 (5,7\%) kasus dari 35 kasus. Ini terjadi pada kasus dengan stadium 4 yang telah menjalani operasi mastoidektomi dinding utuh. ${ }^{17}$

Kontrol pasien yang telah menjalani operasi mastoidektomi terbuka perlu dilakukan secara berkala dalam jangka panjang. Pada masa awal pasca operasi perlu diperhatikan proses epitelisasi kavitas operasi. Jaringan granulasi dapat menghambat proses epitelisasi. Irigasi, pemberian antibiotik lokal dan steroid dapat menghambat terjadinya infeksi maupun pembentukan jaringan granulasi. $^{19,20}$

Pada jangka panjang pasien rutin datang untuk membersihkan kavitas dari desquamsi epitel maupun serumen. Disamping itu perlu diperhatikan adalah komplikasi yang muncul seperti adanya infeksi berulang, terbentuknya kolesteatom atau adanya sisa kolesteatom ini perlu dibersihkan. Pada membran timpani yang masih utuh perlu diperhatikan adanya perforasi akibat infeksi atau terjadinya retraksi. ${ }^{19,20}$

\section{SIMPULAN}

Kolesteatom kongenital merupakan kasus yang jarang terjadi, seringkali terdiagnosis ketika sudah terjadi komplikasi. Abses subperiosteal khususnya abses retroaurikula merupakan salah satu komplikasi kolesteatom kongenital yang sering menjadi awal gejala adanya kolesteatom kongenital. Deteksi dini 
dan tatalaksana yang tepat akan memberikan hasil yang maksimum. Dimana operasi adalah tatalaksana mutlak pada kasus ini.

\section{DAFTAR PUSTAKA}

1. Meyer TA, Strunk CL, Lambert PR. Bailey's Head and Neck Surgery Otolaryngology. Fifth edition. Philadelphia: Lipincott Williams and Wilkins 2015.

2. Maniu A, Harabagiu O, Schrepler MP, Catana A, Fanuta B, Mogoanta CA. Molecular biology of cholesteatoma. Rom J Morphol Embryol. 2014; 55 (1):7-13.

3. Tabook SMS, Abdel Tawab HMA, Gopal NK. Congenital cholesteatomalocalized to the mastoid cavity and presenting as a mastoid abscess. Case Rep Otolaryngol. 2015 April.

4. Migirov L, Carmel E, Dagan E, Duvdevani S, Wolf M. Mastoid subperiosteal abscess as a first sign of unnoticed cholesteatoma in children. Acta paediatrica. 2010;99(1):147-9.

5. Bennett $M$, Warren $F$, Jackson GC, Kaylie D. Congenital cholesteatoma: theories, facts, and 53 patients. Otolaryngologic Clinics of North America. 2006; 39 (6):1081-94.

6. Lee SH, Jang JH, Lee D, Lee HR, Lee KY. Surgical outcomes of early congenital cholesteatoma: minimally invasive transcanal approach. The Laryngoscope. 2014;124(3):755-9.

7. Kobayashi T, Gyo K, Komori M, Hyodo M. Efficacy and safety of transcanal endoscopic ear surgery for congenital cholesteatomas: apreliminary report. Otology \& Neurotology. 2015;36(10):1644-50.

8. Gulya AJ. Developmental anatomy of the temporal bone and skull base. In: Gulya AJ, Poe DS, editor. Surgery Of the Ear. 6th edition. Connecticut: People's Medical Publishing HouseUSA; 2010.p.3.

9. Derlacki EL, Clemis JD. LX: Congenital Cholesteatoma of the Middle Ear and Mastoid. Annals of Otology, Rhinology \& Laryngology.1965;74(3):706-27.

10. Potsic WP, Samadi DS, Marsh RR, Wetmore RF. A staging system for congenital cholesteatoma.
Archives of Otolaryngology-Head \& Neck Surgery. 2002;128(9):1009-12.

11. Tada A, Inai R, Tanaka T, Marukawa Y, Sato S, Nishizaki K, et al. The difference in congenital cholesteatoma CT findings based on the type of mass. Diagnostic and Interventional Imaging. 2016;97(1):65-9.

12. Kaya H, Vural A, Somdaş MA, Öztürk $M$, Doğan $M$. Zygomatic abscess with temporomandibular joint effusion complicating acute otitis media. Erciyes Medical Journal/Erciyes Tip Dergisi. 2016;38(3).

13. Dhingra PL, Dhingra S. Disease of ear, nose, and throat. 6th Edition. India: Elsevier; 2014. 10 p.

14. Smouha E, Bojrab DI. Cholesteatoma. New York: Thieme Medical; 2010. 117-23 p.

15. Robert Y, Carcasset S, Rocourt N, Hennequin C, Dubrulle F, Lemaitre L. Congenital cholesteatoma of the temporal bone: MR findings and comparison with CT. American journal of neuroradiology. 1995;16(4):755-61.

16. Levenson M. Origin of congenital cholestecetoma from a normally occurring epidermoid rest in the developing middle ear. International Journal of Pediatric Otorhinolaryngology. 1988;15(1):51-65.

17. Park KH, Park SN, Chang KH, Jung MK, Yeo SW. Congenital middle ear cholesteatoma in children; retrospective review of 35 cases. Journal of Korean medical science. 2009;24(1):126-31.

18. Steward DL, Choo DI, Pensak ML. Selective indications for the management of extensive anterior epitympanic cholesteatoma via combined transmastoid / middle fossa13 approach. The Laryngoscope. 2000;110(10):1660-6.

19. Dhingra PL, Dhingra S. Disease of ear, nose, and throat. 6th Edition. India: Elsevier; 2014. 67-74 p.

20. Johnson JT, Rosen CA. Bailey's head and neck surgery: Otolaryngology. 5th Editon. Philladephia: Wolters Kluwer Lippincott Williams and Wilkins; 2014. 2253-72 p 